J. Product. \& Dev., 18(3):447-455(2013)

\title{
EFFICIENCY OF NATURAL EXTRACT, Aaloe barbadensis GAINST TWO SPECIES OF PHYTOPHAGOUS MITES
}

Waked, A. Dalia ${ }^{*}$ and Eleawa, M.

Plant Protection Research Institute, ARC, Giza, Egypt.

"Corresponding author email: dr.dalia188@yahoo.com

\begin{abstract}
Three different extracts of Aloe barbadensis Miller leaves were evaluated for acaricidal activity against adult female of mites, Tetranychusurticae and Cenopalpuspulcher by spray bioassay. At $72 \mathrm{~h}$ after treatment the acetone extract showed the strongest acaricidal activity with $L C_{50}$ value of $105 \mathrm{ppm}$ while, the $L C_{50}$ values for ethanol and water extracts were 322 and $366 \mathrm{ppm}$ for T. urticae, respectively. $L C_{50}$ values were 80, 289 and 320 ppm at the same order for extracts against $C$. pulcher. The acetone extract was fractionated using GC-MS analysis to twenty-three fractions. Using $L C_{50}$ of acetone extract a reduction in longevity of adult females of both species occurredas 14.45 and 12.37 days for $T$. urticae and $C$. pulcher, respectively. While, control treatment was 20.27 and 16.18 days for T.urticae and $C$. pulcher, respectively. Acetone extract caused significant reduction on fecundity. Deterrent index were 43.61 and $31.29 \%$ for T.urticae and C. pulcher, respectively. The obtained results indicated that A.barbadensis has a great potential as a botanical acaricide for $T$. urticae and $C$. pulcher control.

Conclusively, from these results of the present study show great potential and must be more advanced for developing Aloe extracting based mite control products.
\end{abstract}

Keywords: Aloe barbadensis, Cenopalpuspulcher, Tetranychusurticae

\section{INTRODUCTION}

Mites belonging tothe families, tetranychidae and tenuipalpidae (Acari: Prostigmata) can be regarded as some of the most destructive of the plant feeding species. The tenuipalpidae species are known as flat mites or false spider mites and worldwide in distribution. Tenuipalpidae species are phytophagous and damage plants by sucking on the epidermal cells. Most of the species can cause economic damage to cultivated and ornamental plants (Ripka, 1998; Didem and Sultan 2010). C. pulcher is considered one of the major pest followed this family.The tetranychidae, $T$. urticae is a phytophagous pest that infests over 100 crop species including beans, 
cucumbers, eggplants, tomatoes, and cucurbits grown in field and greenhouse throughout the world (Cakmaket al., 2005). For the past several decades, the control of mites has depended mainly on application of pesticides. The extensive use of pesticides has led to rapid development of resistance in this mite. Besides the extensive and long-term use of chemical pesticides have serious adverse effects on beneficial organisms, humans and the environment. Therefore, identification and development of effective, anti-resistance, safe and eco-friendly non chemical control alternatives for mites are needed. Use of natural compounds from plant extracts has been suggested as a viable source of alternative treatments for insect and mite control because many substances of such compounds have novel modes of action, no or low toxicity to non-target organisms and mammals, and are less harmful to the environment (Schmutterer, 1997). Numerous plant extracts have been reported to have different biological activities against insects and mites including repellence, feeding and oviposition deterrence, toxicity, and growth regulatory activity (Singh and Saratchandra, 2005). Moreover, plant based pesticides often contain a mixture of active substances, which can delay or prevent resistance development (Wang et al., 2007). A. barbadensis is one of Liliaceae family. A. barbadensis's biological activity is widely accepted and it is used for various medical, cosmetic and nutraceutical purposes. Compared to the benefits of Aloe to humans, relatively little is known about its insecticidal and/or acaricidal activities.

Therefore, the objectives of this study were to assess acaricidal activity of $A$. barbadensis against the mite pests and to isolate active components in an effort to gain information on developing new Aloe based pesticides for mite control that are effective and safe.

\section{MATERIALS AND METHODS}

\section{Tested animals}

The stock culture started with females collected from eggplantand navel orangefrom a farm in Sharkia Governorate. The eggplant leaves (Solanummelongena) infested by the two-spotted spider mites, T. urticae and navel orange leaves, Citrus sinensis infested by $C$. pulcher, were collected and placed in paper bags. Samples were transferred immediately to the laboratory. The mass culture was initiated by transferred individuals of females and males using a camel's hair brush placed in petri-dishes about10 $\mathrm{cm}$ diameter, which provided with untreated fresh leaves discs of mulberry (Morus alba L.) for T. urticae and discs of Citrus sinensis for C. pulcher about $3 \mathrm{~cm}$ diameter placed on a pad of cotton wool, fully saturated with water as a source of moisture and to prevent mite escaping. Newly laid eggs 
were obtained by releasing the adult females on fresh and clean mulberry and navel orange leaf discs overnight and removing all the adult females at the next day. After eggs hatching, the newly larvae were placed on fresh leaf discs in prepared petri-dished as mentioned above. The old leaf discs were removed after one day and mites were fed on fresh leaf discs, wherever, it was necessary about 4-6 changes, to complete lifecycle of the experimental mites. All colonies were kept in an incubator at $28 \pm 2{ }^{\circ} \mathrm{C}$ and $65 \pm 5 \%$ R.H. The population density of mites in each colony was kept by providing of fresh host plants.

\section{Plant material collection and extraction}

The plant of Aloe barbadensis (leaves) was collected from Zagazig district. The leaves of Aloe barbadensis were air dried and crushed to small pieces using mortar and pestle then powdered in an electric grinder. Twenty grams of powdered plant materials were mixed with $100 \mathrm{ml}$ of various solvents (distilled water, ethanol and acetone solution). The extracts preparations were done as previously described by Alade and Irobi (1993). Phytochemical components were analyzed qualitatively. The GC-MS analysis of the A. barbadensis was performed.

\section{Bioassay tests:}

\section{Effects on adult females of mite:}

The spray technique was applied to test the efficacy of the different extracts on females of $T$. urticae and $C$. pulcher. Eight replicates of mulberry leaf for $T$. urticae treated and navel orange for $C$. pulcher were done, each disc about $3 \mathrm{~cm}$ diameter was gently sprayed with serial of concentrations of each experimented extract. Ten adult females at the same age of laboratory reared mite colony were individually transferred by means of a camel hair brush to treated leaf discs of mulberry and navel orange. For conserving leaf discs fresh, water moist cotton pad below the leaf disc equipped each petridish. For each concentration, total numbers of 80 adult females were tested for each mite. Also, 8 petri-dishes equipped with the same number of adult mite females on water treated leaf discs were used as control. All petri-dishes were held at the same conditions of $28 \pm 2{ }^{\circ} \mathrm{C}$ and relative humidity of $65 \pm 5$ $\%$ R.H. These techniques were made according to Ebeling (1960). Mites treated with different extracts were examined daily and mortality \% was calculated. The efficiency of different plant extracts was measured by comparing the tested extract with the most effective extract by using the equation of Sun (1950).

$$
\text { Toxicity index }=\frac{\text { LC50 of the most eff ective one }}{\text { LC50 of the tested extract }} \times 100
$$


2. Latent effect of $L C_{50}$ of some extracts on longevity and fecundity of $T$. urticae and $C$. pulcher females:

Eight adult individuals of $T$. urticae and $C$. pulcher were transferred to mulberry and navel orange leaf discs about $3 \mathrm{~cm}$ diameter, respectively. Treatments were replicated 10 times for each species, $T$. urticae and $C$. pulcher. The spray technique was applied as mentioned above. The live individuals from each species were observed then the longevity and fecundity of $T$. urticae and $C$. pulcher were recorded. Deterrent indices for adult females were calculated according to Lundgren (1975) formula as follow:

Deterrent index $\%=\frac{\mathbf{B}-\mathbf{A}}{\mathbf{B}+\mathbf{A}} \times 100$

A: Number of eggs in treatment, B: Number of eggs in control.

\section{Statistical analysis:}

Data were analyzed with one-way ANOVA followed by Duncan, (1955) multiple range tests at $\mathrm{P}<0.05$ using Costat.

\section{RESULTS}

Table (1) cleared that the acetone extract was the most effective against adult females of $T$. urticae, while water extract was the least effective. $\mathrm{LC}_{50}$ for tested extracts can be arranged as the following descending order: acetone, ethanol and water extracts since $\mathrm{LC}_{50}$ values for them were 105, 322 and 366 ppm, respectively. On the other hand, C. pulcher was more sensitive for the extracts compared with $T$. urticae, where $\mathrm{LC}_{50}$ values were 80, 289 and 320 $\mathrm{ppm}$, respectively. for the same previous order. According to the toxicity index at $\mathrm{LC}_{50}$ the most potent extract was acetone $(100 \%)$ for both mites, while the least one was water (28.68 and $25.00 \%)$ for both mites.

Table 1. Comparative toxicity of three extracts against the two species of mites after $72 \mathrm{hr}$.

\begin{tabular}{|c|c|c|c|c|c|c|c|c|}
\hline \multirow{3}{*}{ Extracts } & \multicolumn{2}{|c|}{$\mathbf{L C}_{50}(\mathrm{ppm})$} & \multicolumn{2}{|c|}{ Toxicity index \% } & \multicolumn{4}{|c|}{ Confidence limits for $\mathrm{LC}_{\mathbf{5 0}}$} \\
\hline & \multirow{2}{*}{$\begin{array}{c}T . \\
\text { urticae }\end{array}$} & \multirow{2}{*}{$\begin{array}{c}C . \\
\text { pulcher }\end{array}$} & \multirow{2}{*}{$\begin{array}{c}T . \\
\text { urticae }\end{array}$} & \multirow{2}{*}{$\begin{array}{c}C . \\
\text { pulcher }\end{array}$} & \multicolumn{2}{|c|}{ T.urticae } & \multicolumn{2}{|c|}{ C.pulcher } \\
\hline & & & & & Upper & Lower & Upper & Lower \\
\hline Acetone & 105 & 80 & 100 & 100 & 117 & 96 & 94 & 69 \\
\hline Ethanol & 322 & 289 & 32.61 & 27.68 & 346 & 309 & 302 & 265 \\
\hline Water & 366 & 320 & 28.68 & 25.00 & 382 & 347 & 336 & 311 \\
\hline
\end{tabular}

The acetone extract shortened the longevity and reduced the fecundity of adult females of T. urticae and C. pulcher. Results in Table (2) 
revealed that, the pre-oviposition period when used acetone extract were 1.63 and 1.96 days for $T$. urticae and $C$. pulcher, respectively. Compared with 1.41 and 1.84 days for the control. On the other hand, oviposition period was 10.21 and 8.52 days for the previous order compared with 16.56 and 12.11 days for the control. Longevity of individuals was 14.45 and 12.37 days for $T$. urticae and $C$. pulcher compared with 20.27 and 16.18 days for the control. Concerning, the total number of eggs was 21.17 and 20.74 eggs for $T$. urticae and $C$. pulcherand 53.92 and 39.63 eggs for control. The acetone extract caused deterrent index $\% 43.61$ and 31.29 for $T$. urticae and $C$. pulcher, respectively.

Table 2. Effect of $\mathrm{LC}_{50}$ for acetone extract on longevity and fecundity of two species mites'females.

\begin{tabular}{|c|c|c|c|c|c|c|}
\hline $\begin{array}{c}\text { Mite } \\
\text { species }\end{array}$ & $\begin{array}{c}\text { Pre- } \\
\text { oviposition }\end{array}$ & Oviposition & $\begin{array}{c}\text { Post- } \\
\text { oviposition }\end{array}$ & $\begin{array}{c}\text { Longevity } \\
\text { (days) }\end{array}$ & Fecundity & $\begin{array}{c}\text { Deterrent } \\
\text { index, \% }\end{array}$ \\
\hline T. urticae & 1.63 & 10.21 & 2.61 & $14.45 \mathrm{~b}$ & $21.17 \mathrm{~b}$ & 43.61 \\
\hline Control & 1.41 & 16.56 & 2.30 & $20.27 \mathrm{a}$ & $53.92 \mathrm{a}$ & - \\
\hline C. pulcher & 1.96 & 8.52 & 1.89 & $12.37 \mathrm{~b}$ & $20.74 \mathrm{~b}$ & 31.29 \\
\hline Control & 1.84 & 12.11 & 2.23 & $16.18 \mathrm{a}$ & $39.63 \mathrm{a}$ & - \\
\hline
\end{tabular}

Means in columns followed by the same letters are not significantly different at $\mathrm{p}=5 \%$ according to Duncan's multiple range test (Duncan, 1955)

Table (3) indicated that the GC-MS analysis, 23 bioactive phytochemical compounds were identified in the acetone extract of Aloe barbadensis. The identification of phytochemical compounds is based on the peak area, molecular weight and molecular formula.

\section{DISCUSSION}

Plant based acaricides have long been recommended as alternatives to synthetic chemical acaricides for pest control because these chemicals pose little threat to the environment and/or to human health (Isman, 2006). Pipernonaline and piperoctadecalidine, two alkaloids isolated from Piper longum L., were also potent against $T$. urticae (Park et al., 2002). This study investigates the contact acaricidal, repellent, fumigant, and oviposition inhibition activities of the acetone extract of A. veraL. leaf against Tetranychuscinn abarinus. The aloe acetone extract was found to have good contact acaricidal activity against the cinnabar of female adult mites. Through the toxicity regression line of the aloe acetone extract against female carmine spider mites, the $\mathrm{LC}_{50}$ values to $T$. cinnabarinus were found to be 0.836 and $0.167 \mathrm{mg} / \mathrm{mL}$ for 48 and $72 \mathrm{~h}$, respectively. (Wei et al., 2011) reported $\mathrm{LC}_{50}$ values of 0.614 and $0.099 \mathrm{mg} / \mathrm{mL}$ for 48 and $72 \mathrm{~h}$, respectively. The main modes of action of the extract against adult mites' females were contact and repellent, and preferable effects were observed on adult mites. These results indicate that $A$. vera L. extract contains acaricidal and repellent 
Table 3: Phytocomponents identified in the plant sample extract

\begin{tabular}{|l|c|l|l|}
\hline & RT/min. & Name of the Compound & Molecular Formula \\
\hline 1 & 16.05 & 1-Tetradecyne & $\mathrm{C}_{14} \mathrm{H}_{26}$ \\
\hline 2 & 17.67 & Tridecanoic acid, methyl ester & $\mathrm{C}_{14} \mathrm{H}_{28} \mathrm{O}_{2}$ \\
\hline 3 & 18.70 & n-Hexadecanoic acid & $\mathrm{C}_{16} \mathrm{H}_{32} \mathrm{O}_{2}$ \\
\hline 4 & 18.93 & Hexadecanoic acid, ethyl ester & $\mathrm{C}_{18} \mathrm{H}_{40} \mathrm{O}$ \\
\hline 5 & 21.07 & Phytol & $\mathrm{C}_{20} \mathrm{H}_{4} \mathrm{O}$ \\
\hline 6 & 21.85 & Oleic Acid & $\mathrm{C}_{18} \mathrm{H}_{34} \mathrm{O}_{2}$ \\
\hline 7 & 22.06 & $9,12,15$ - Octadecatrienoic acid methyl ester, (ZZZ) & $\mathrm{C}_{19} \mathrm{H}_{32} \mathrm{O}_{2}$ \\
\hline 8 & 24.13 & Oxalic acid, allylpentadecyl ester & $\mathrm{C}_{20} \mathrm{H}_{36} \mathrm{O}_{4}$ \\
\hline 9 & 25.73 & Oxalic acid, allylhexadecyl ester & $\mathrm{C}_{21} \mathrm{H}_{38} \mathrm{O}_{4}$ \\
\hline 10 & 27.11 & 9-Ocatadecenal & $\mathrm{C}_{18} \mathrm{H}_{34} \mathrm{O}$ \\
\hline 11 & 28.48 & 1-Octadecyne & $\mathrm{C}_{18} \mathrm{H}_{34}$ \\
\hline 12 & 28.77 & Sulfurous acid, hexyl pentadecyl ester & $\mathrm{C}_{21} \mathrm{H}_{44} \mathrm{O}_{3} \mathrm{~S}$ \\
\hline 13 & 30.21 & 1-lodo-2-methylundecane & $\mathrm{C}_{12} \mathrm{H}_{25}$ \\
\hline 14 & 31.60 & Eicoane & $\mathrm{C}_{20} \mathrm{H}_{42}$ \\
\hline 15 & 31.90 & Squalene & $\mathrm{C}_{30} \mathrm{H}_{50}$ \\
\hline 16 & 32.95 & Octadecane, 2-methyl- & $\mathrm{C}_{19} \mathrm{H}_{40}$ \\
\hline 17 & 34.26 & Nonadecane, 2-methyl & $\mathrm{C}_{20} \mathrm{H}_{42}$ \\
\hline 18 & 36.09 & Vitamin E & $\mathrm{C}_{29} \mathrm{H}_{50} \mathrm{O}_{2}$ \\
\hline 19 & 36.80 & Sulfurous acid, butyl heptadecyl ester & $\mathrm{C}_{21} \mathrm{H}_{44} \mathrm{O}_{3} \mathrm{~S}$ \\
\hline 20 & 37.38 & 9, 12-Octadecadienoic acid (Z,Z)-, phenylmethyl ester & $\mathrm{C}_{25} \mathrm{H}_{38} \mathrm{O}_{2}$ \\
\hline 21 & 38.25 & Tetracontane, 3, 5, 24-trimethyl- & $\mathrm{C}_{43} \mathrm{H}_{88}$ \\
\hline 22 & 38.78 & -Sitosterol & $\mathrm{C}_{29} \mathrm{H}_{50} \mathrm{O}$ \\
\hline 23 & 40.28 & Lupeol & $\mathrm{C}_{30} \mathrm{H}_{50} \mathrm{O}$ \\
\hline
\end{tabular}

RT: Retention time/minute

bioactive components that may be useful in future control of the phytophagous mites (Zhang et al., 2013). In this study there were found some compounds which isolated from Aloe extract caused mortality percent for genus Tetranychus, these compounds were Lupeol (Wang et al., 2012), Oliec acid (Eleawa, 2007) Sulfurous acid, 9,12Octadecadieoic acid (Z, Z) (Lucie, et al. 2013). We forced our efforts to search alternative methods for controlling mite based on Aloe because the plants are readily available around the world, they have been used extensively for medical, nutritional and cosmetical purposes and they pose a minimal threat to humans and the environment.

Conclusively, from these results of the present study show great potential and must be more advanced for developing Aloe extracting based mite control products. 


\section{REFERENCES}

Alade, P. I. and O.N. Irobi (1993). Antimicrobial activities of crude leaf extracts of Acalyphawilkensiana. Journal of Ethnopharmacology. 39: 171-174.

Cakmak; H. Baspinar and N. Madanlar (2005). Control of the carmine spider mite Tetranychuscinn abarinus Boisduval by the predatory mite Phytoseiuluspersimilis (Athias- Henriot) in protected strawberries in Aydin, Turkey. Turkey Journal of Agri. Fore., 29: 259-265.

Didem H. S. and C. Sultan (2010). Determination of Tenuipalpidae (Acari: Prostigmata) species in parks and ornamental plants of Ankara, Turkey. Türk. entomol. derg., 34 (1): 37-52

Duncan, D. B. (1955). Multiple range and multiple $F$ - tests. Biometrics, 11:1-42.

Ebeling, W. (1960). Testing Acaricides. In: Harold H. Shepard (ed.). Methods of testing chemicals and insects. Burgess Publishing Co. Minneapolis. II, 156-192.

Eleawa, M. S. (2007).Studies on some phytophagous mites in Sharkia Governorate. M. Sc. Thesis, Fac. Agric., Zagazig Univ., 129 pp.

Isman, M. B. (2006).Botanical insecticides, deterrents, and repellents in modernagriculture and an increasingly regulated world. Annu. Rev. Entomol., 51: 45-66.

Lucie A.; S. Dogo, L. Didier Ponel Béranger; Bolevane Ouantinam Serge Florent; Gueye Momar Talla; Traoré Anna; Namkosséréna Salomon; Noba Kandioura; Sembène Mbacké and Syssa-Magalé Jean-Laurent(2013). Chemical Characterization and Insecticidal Activity of Ethyl Acetate and Dichloromethane Extracts of Drypetesgossweileri against Sitophiluszeamais, Triboliumcastaneumand Rhyzoperthadominica. Journal of Life Science, 7(10): 1030-1040.

Lundgren, L. (1975). Natural plant chemicals acting as oviposition deterrents on cabbage butterflies, Pierisbrassicae (L.), P. rapa (L.) and $P$. napi (L.). Zoll. Ser., 4: 250-258.

Park, B. S.; S. E. Lee; W. S. Choi; C. Y. Jeong; C. Song and K. Y. Cho (2002). Insecticidal and acaricidal activity of pipernonaline and piperoctadecalidine derived from dried fruits of Piper longum L. Crop. Prot., 21: 249-251.

Ripka, G. (1998). New data to the knowledge on the Tetranychid and Tenuipalpid fauna in Hungary (Acari: Prostigmata). Acta Phytopathologicaet Entomologica Hungarica, 33 (3-4): 425-433. 
Schmutterer, H. (1997). Side effects of neem (Azadirachtaindica) products on insect pathogens and natural enemies of spider mites and insect. Journal of Appl. Entomol., 12: 121-128.

Singh, R.N. andB.Saratchandra,(2005). The development of botanical products with special reference to seri-ecosystem. Caspian Journal of Env. Sci., 3: 1-8.

Sun, Y. P. (1950). Toxicity index an improved method of comparing the relative toxicity of insecticides. Journal of Econ. Entomol., 43: 4553.

Wang, Y.; D. Duan; J. Cheng; Y. Liu; G. Shi; B. Tong (2012). Acaricidal Activity of Lupeol from Inulabritanica against Tetranychuscinn abarinus (Acari: Tetranychidae). Information Tech. and Agricultural Eng., AISC134: 713-719

Wang, Y. N.; G.L. Shi; L. L. Zhao; S. Q. Liu; T. Q. Yu; S. R. Clarke and J. H. Sun, (2007). Acaricidal activity of Juglansregia leaf extracts on Tetranychusviennensis and Tetranychuscinn abarinus (Acari: Tetranychidae). Journal of Econ. Entomol., 100: 12981303.

Wei, J.;W. Ding;Y.G. Zhao and V.Patcharaporn, (2011). Acaricidal activity of Aloe veraL. leaf extracts against Tetranychuscinn abarinus (Boisduval) (Acarina: Tetranychidae). Journal of Asia- Pacific Entomology, 14: 353-356.

Zhang Q.; L. Ding; M. Li; W. Cui; W. Ding; J. Luo and Y. Zhang (2013).Action modes of Aloe vera L. extracts against Tetranychuscinn abarinus Boisduval (Acarina: Tetranychidae). Agricultural Sciences, 4(3): 117-122
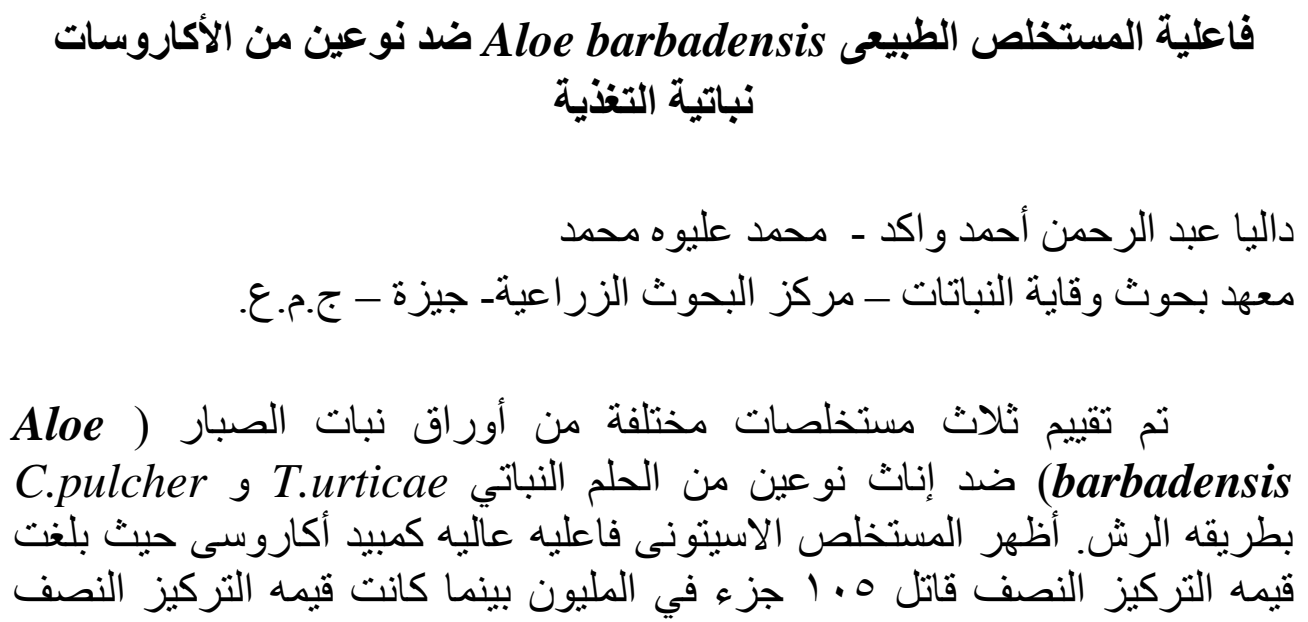


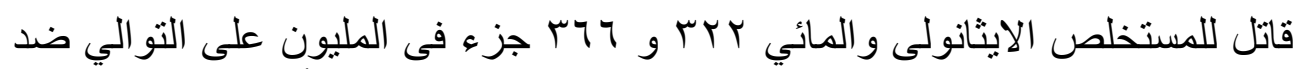

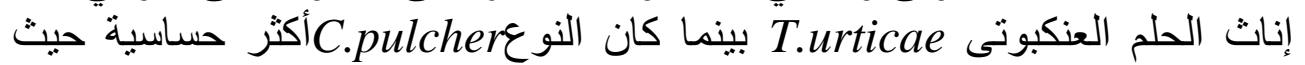

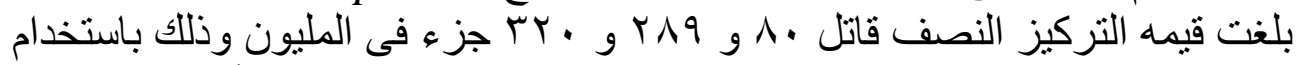

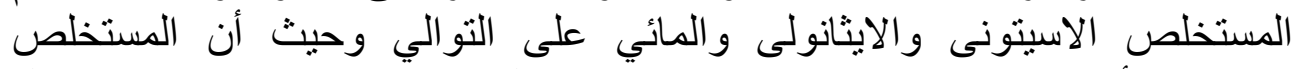

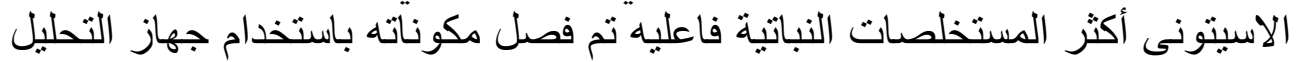

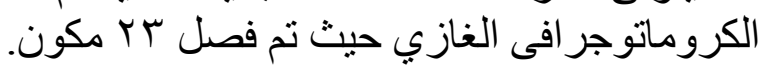

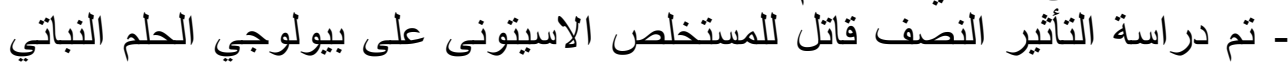
C.pulcher gT.urticae بلغت مده معيشه اناث النوع Iurticae مقارنه بالكنترول V.pulcher

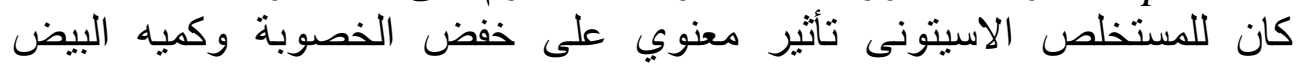

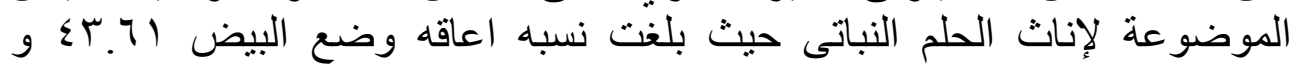

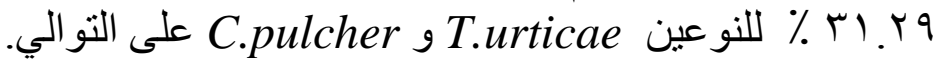

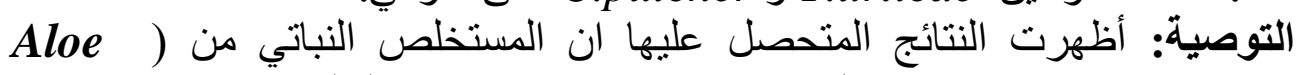
(barbadensis 